\title{
Mechanism of increased osmotic resistance of red cells in workers exposed to lead
}

\author{
I KARAI, ${ }^{1}$ K FUKUMOTO, ${ }^{2}$ AND S HORIGUCHI ${ }^{1}$
}

From the Department of Preventive Medicine and Public Health, ${ }^{1}$ Osaka City University Medical School, Abeno-ku, Osaka, 545, and Osaka Prefectural Institute of Occupational Health, ${ }^{2}$ Higashi-ku, Osaka, 540, Japan

ABSTRACT In order to clarify the mechanism of the increased osmotic resistance of red blood cells in lead workers 19 men employed in a lead refining factory and 18 control male workers employed in railway construction were examined for red cell count, haematocrit, MCV, blood and urine lead concentrations, urine coproporphyrin and $\delta$-aminolevulinic acid, osmotic resistance of red cells, lecithin-cholesterol acyltransferase (LCAT) activity in serum, and cholesterol content and cholesterolto-phospholipid ratio of the red cell membrane. The results were: (1) The osmotic resistance of the red cells $(p<0.05)$, cholesterol content of the red cell membrane, blood and urine lead, urine coproporphyrin, and urine $\delta$-ALA concentrations $(\mathrm{p}<0.01)$ were higher in the lead workers than in the controls. (2) In the lead workers close relationships were observed between the osmotic resistance and the blood lead concentration $(\mathrm{r}=-0.515, \mathrm{p}<0.05)$, osmotic resistance and LCAT activity $(r=0.596, p<0.01)$, and osmotic resistance and cholesterol of the red cell membrane $(\mathrm{r}=-0.492, \mathrm{p}<0.05)$.

An increase in the osmotic resistance of red blood cells has been observed in lead workers using a coil planet centrifuge system..$^{1-4}$ There is a dose-response relationship between the osmotic resistance of red cells and the blood lead concentration. The mechanism of the increased osmotic resistance in lead poisoning has not been completely clarified, however.

Recently, Cooper et $a^{5-7}$ reported an increase in osmotic resistance of red cells in patients with obstructive jaundice and also a close relationship between increased osmotic resistance and an increased cholesterol-to-phospholipid ratio in the red cell membrane. Cooper concluded that membrane cholesterol was the major factor affecting osmotic resistance.

The present report describes changes in red cell osmotic resistance and cholesterol in lead workers and clarifies the mechanism of the increased osmotic resistance.

\section{Materials and methods}

Nineteen men aged 32-73 (mean 48) exposed to lead

Received 15 June 1981

Accepted 13 July 1981 in a scrap lead refining factory were studied, while 18 men aged 30-57 (mean 41.1) employed in railway construction served as controls. Workers with disordered liver function were excluded.

Blood sample were taken from a cubital vein into heparinised test tubes for the following examinations.

Osmotic fragility of red cells-The coil planet centrifuge system (Sanki Engineering Ltd, Japan) was used. Three haemolysis points (of the starting point, HSP; of the maximum point, HMP; and of the end point, HEP) of the haemoglobin distribution pattern in the coil tube were determined by scanning photodensitometer ${ }^{2}$ (fig 1 ).

Red cell count-An automatic blood cell counter (Coulter Counter, Model ZF, Coulter Electronics, USA) was used.

Haematocrit-The capillary tube method was used. The mean corpuscular volume was calculated by dividing the haematocrit value by the red cell count.

Lecithin-cholesterol acyltransferase (LCAT) activity in serum-The enzymatic method ${ }^{8}$ without EDTA was used.

Preparation of the red cell membrane-After removal of the serum and buffy coat, red cells were washed three times with $0.15 \mathrm{M} \mathrm{NaCl}$ and lysed with deionised water. The ghosts were washed with $2.5 \mathrm{mM}$ Tris- $\mathrm{HCl}$ buffer $(\mathrm{pH} 7.5)$ several times to 


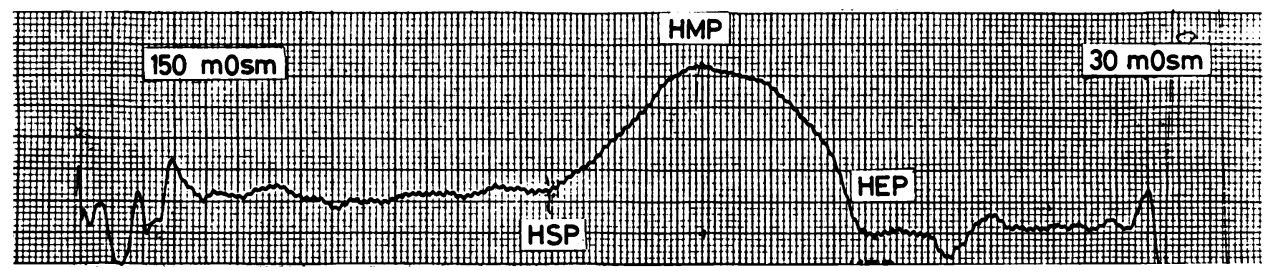

Fig 1 Osmotic fragility curve of normal human blood determined with a coil planet centrifuge. Ten microlitres of blood was put into a coiled tube and forced by centrifugation through a saline solution having a linear osmotic gradient with a range of 150-30 mOsmol. Thus red cells were exposed to gradually changing osmotic pressure down to a point where haemolysis occurred. The haemoglobin distribution pattern in the coiled tube was recorded by scanning photodensitometer. Three points of haemolysis (of the starting point, HSP; of the maximum point, HMP; and of the end point, HEP) were observed.

remove haemoglobin completely from the membrane.

Cholesterol of the red cell membrane--Five microlitres of $10 \%$ dodecyl sodium sulphate (SDS) were added to $20 \mu \mathrm{l}$ of dispersed membrane fragments and total cholesterol was measured by an enzymatic method. ${ }^{9}$

Protein of the red cell membrane-After dissolving the membrane fragments with $10 \%$ SDS, the protein content was measured by the method of Lowry et al. ${ }^{10}$ The amount of total cholesterol of red cell membrane was calculated by dividing the total cholesterol value by the protein concentration of the membrane.

Phospholipid of the red cell membrane-Total phospholipid was determined for inorganic phosphorus by the method of Shin. ${ }^{11}$ The ratio of cholesterol-to-phospholipid of red cell membrane was calculated by dividing the total cholesterol value by the phospholipid value of red cell membrane.

Blood and urine lead-The dithizone-polarography ${ }^{12}$ was used.

Urine $\delta$-aminolevulinic acid $(\delta-A L A)$-The method of Tomokuni and Ogata ${ }^{13}$ was used.

Urine coproporphyrin-The method of Rimington modified by Sano and Granick ${ }^{14}$ was used.

Statistical significance was tested by Student's $t$-test.

\section{Results}

The osmotic resistance of the red cells of the two

Table 1 Osmotic resistance (mOsm) of red blood cells by CPC method in lead workers and controls

\begin{tabular}{lll}
\hline & $\begin{array}{l}\text { Lead workers } \\
(n=19)\end{array}$ & $\begin{array}{l}\text { Controls } \\
(n=18)\end{array}$ \\
\hline Haemolysis of starting point & $56 \cdot 7 \pm 3 \cdot 89^{*}$ & $59 \cdot 2 \pm 2 \cdot 41$ \\
Haemolysis of maximum point & $73.6 \pm 4 \cdot 12^{*}$ & $77.0 \pm 3 \cdot 25$ \\
Haemolysis of end point & $94.5 \pm 5 \cdot 29$ & $95.4 \pm 4.68$ \\
\hline *Significant difference at p $<0.05$. &
\end{tabular}

groups is shown in table 1 ; tables 2 and 3 show the results of the other tests. The values for cholesterol and cholesterol-to-phospholipid ratio of the red cell membrane, blood and urine lead concentrations, and urine coproporphyrin and $\delta$-ALA concentrations were higher in the lead workers than in the controls, while the values for osmotic fragility, red cell count, haematocrit, and LCAT activity were lower. The mean corpuscular volumes were almost the same for the two groups. We found significant differences in osmotic resistance (HMP and HEP) $(p<0.05)$, membrane cholesterol $(p<0.01)$, blood and urine lead $(\mathrm{p}<0.01)$, urine copropor-

Table 2 Clinical laboratory data for lead workers and controls

\begin{tabular}{|c|c|c|}
\hline & $\begin{array}{l}\text { Lead workers } \\
(n=19)\end{array}$ & $\begin{array}{l}\text { Controls } \\
(n=18)\end{array}$ \\
\hline Red blood cell $\left(10^{4} / \mathrm{mm}^{3}\right)$ & $467 \pm 40$ & $493 \pm 47$ \\
\hline Haematocrit $(\%)$ & $43 \cdot 6 \pm 3 \cdot 1$ & $46 \cdot 0 \pm 3 \cdot 3$ \\
\hline Mean corpuscular volume $\left(\mu^{3}\right)$ & $93 \cdot 8 \pm 9 \cdot 1$ & $93 \cdot 6 \pm 5 \cdot 3$ \\
\hline $\begin{array}{l}\text { Lecithin-cholesterol } \\
\text { acyltransferase in serum (U) }\end{array}$ & $105 \pm 46$ & $127 \pm 57$ \\
\hline $\begin{array}{l}\text { Cholesterol in red cell } \\
(\mathrm{mg} / \text { protein } \mathrm{mg})\end{array}$ & $244 \pm 17 * *$ & $226 \pm 15$ \\
\hline $\begin{array}{l}\text { Cholesterol/phospholipid ratio } \\
\text { in red cell }\end{array}$ & $0.83 \pm 0.033$ & $0.79 \pm 0.022$ \\
\hline
\end{tabular}

**Significant difference at $p<0.01$.

Table 3 Lead exposure levels for lead workers and controls

\begin{tabular}{|c|c|c|c|c|}
\hline & \multicolumn{2}{|c|}{ Lead workers $(n=19)$} & \multicolumn{2}{|c|}{ Controls $(n=18)$} \\
\hline & $\begin{array}{l}\text { Geometric } \\
\text { mean }\end{array}$ & $\begin{array}{l}\text { Dispersion } \\
\text { factor }\end{array}$ & $\begin{array}{l}\text { Geometric } \\
\text { mean }\end{array}$ & $\begin{array}{l}\text { Dispersion } \\
\text { factor }\end{array}$ \\
\hline \multirow{5}{*}{$\begin{array}{l}\text { Blood lead }(\mu \mathrm{g} / \mathrm{dl}) \\
\text { Urine lead }(\mu \mathrm{g} / \mathrm{l}) \\
\text { Urine } \delta \text {-ALA } \\
\quad(\mathrm{mg} / \mathrm{l}) \\
\text { Urine copro }(\mu \mathrm{g} / \mathrm{l})\end{array}$} & $41 \cdot 6$ & $1 \cdot 26 * *$ & $5 \cdot 89$ & $1 \cdot 41$ \\
\hline & $119.8 \pm$ & $1 \cdot 74^{* *}$ & $10 \cdot 8$ & 1.42 \\
\hline & & & & \\
\hline & $9 \cdot 13$ & $3 \cdot 34^{* *}$ & $2 \cdot 25$ & $1 \cdot 33$ \\
\hline & 66.0 & $3 \cdot 85^{* *}$ & $12 \cdot 3 \pm$ & $1 \cdot 80$ \\
\hline
\end{tabular}

ALA $=$ Aminolevulinic acid; copro, coproporphyrin. **Significant difference at $p<0.01$. 


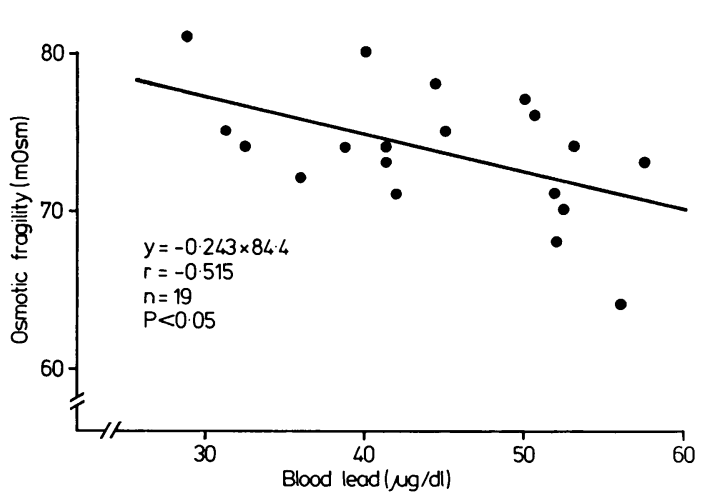

Fig 2 Relationship between blood lead and osmotic resistance in lead workers.

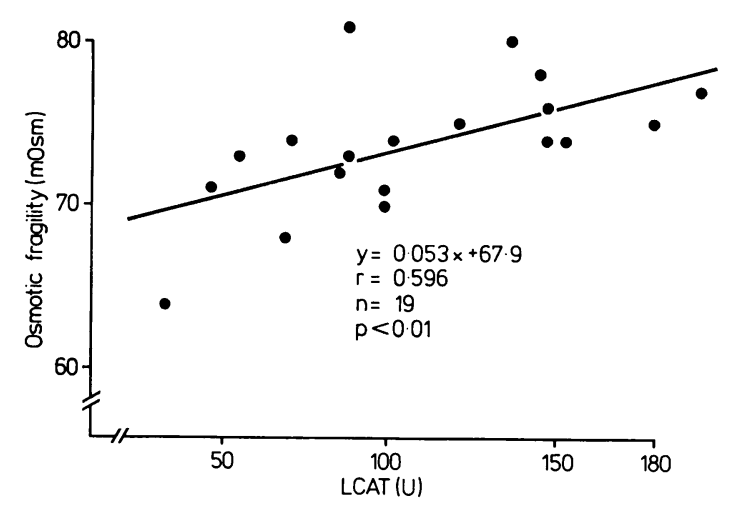

Fig 3 Relationship between lecithin-cholesterol acyltransferase activity and osmotic resistance in lead workers.

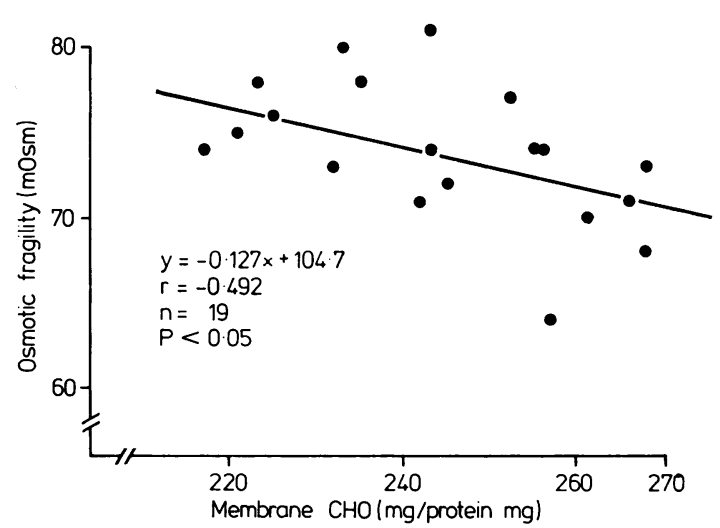

Fig 4 Relationship between cholesterol of red cell membrane and osmotic resistance in lead workers. phyrin $(\mathrm{p}<0.01)$, and urine $\delta$-ALA $(\mathrm{p}<0.01)$, but not in red cell count, haematocrit, LCAT activity, and cholesterol-to-phospholipid ratio of red cell membrane.

There were significant correlations in the lead workers between blood lead and osmotic resistance(HMP) $(\mathrm{r}=-0.515, \mathrm{p}<0.05)$, LCAT activity and osmotic resistance (HMP) $(r=-0.596, p<0.01)$ and cholesterol of the red cell membrane and osmotic resistance (HMP) $(r=-0.492, p<0.05)($ figs $2-4)$.

\section{Discussion}

Aub et al ${ }^{15}$ showed an increased osmotic resistance in red cells treated with lead in vivo and in vitro. These changes result from alterations in the structure of the red cell membrane, but the exact mechanisms of the increased osmotic resistance are not completely understood. For the in-vitro conditions the following hypothesis has been proposed. Lead causes a leakage of potassium but not sodium from red blood cells; a dimunution in cell volume follows and hence an increased ratio of cell surface area to cell volume, allowing more water to enter the cell before it takes the critical spherical form that leads to haemolysis. ${ }^{16}$ The same hypothesis cannot be applied to the in-vivo condition, however, because a decrease in intracellular potassium has not been observed in lead workers. ${ }^{17}$

Cooper et $a^{5-7}$ reported an increased osmotic resistance in patients with obstructive jaundice and summarised their results as follows: (1) An increased amount of bile salts in patients with obstructive jaundice inactivates LCAT. (2) Inactivation of LCAT causes accumulation of cholesterol and the cholesterol-to-phospholipid ratio of the red cell membrane. (3) Accumulation of cholesterol increases the surfaceto-volume ratio of red blood cells. (4) Affected cells have a normal volume but an increased surface area, which gives them a broad, flat appearance described by the term "target cell." (5) The increased surface-to-volume ratio of red blood cells is definitely related to the osmotic resistance.

LCAT is an enzyme controlling cholesterol esterification in plasma and is derived from liver parenchymal cells. Therefore, inactivation of LCAT increases free cholesterol in serum, which is followed by free cholesterol accumulation in the red cell membrane.

We found a higher cholesterol-to-phospholipid ratio of the red cell membrane in lead workers than in controls in this study, but the difference between the two groups was not significant. Therefore, we assume that the increased osmotic resistance occurs through the following mechanism: a raised concentration of blood lead inactivates LCAT indirectly, 
through impairment of the liver parenchyma, or directly. This is followed by the accumulation of cholesterol in the red cell membrane and an increment in the red cell surface, which leads to increased osmotic resistance. This hypothesis is almost the same as that for the formation of the target cell in a patient with obstructive jaundice.

This study has thus clarified the close relationships between increased osmotic resistance and increased cholesterol of the red cell membrane. From these observations, we assume that the major factor of the increased osmotic resistance in lead workers is the increase of cholesterol in the cell membrane.

\section{References}

${ }^{1}$ Horiguchi S, Teramoto $\mathrm{K}$, Nakano $\mathrm{H}$, Shinagawa K, Endo G, Kiyota I. Osmotic fragility test of red blood cells of lead workers by coil planet centrifuge. Osaka City Med J 1974;20:51-3.

${ }^{2}$ Horiguchi S, Teramoto K, Nakano H, Shinagawa K, Endo G, Kiyota I. Relationship between osmotic fragility of red blood cells by coil planet centrifuge and peripheral blood findings in lead workers. Osaka City Med $J$ 1975;21:55-8.

${ }^{3}$ Ito Y, Weinstein MA, Aoki I, Harada R, Kimura E, Nunogaki K. The coil planet centrifuge. Nature 1966; 212:985-7.

${ }^{4}$ Karai I, Fukumoto K, Horiguchi S. Studies on osmotic fragility of red blood cells determined with a coil planet centrifuge for workers occupationally exposed to lead. Int Arch Occup Environ Health (in press).

${ }^{5}$ Cooper RA, Jandl JH. Bile salts and cholesterol in the pathogenesis of target cells in obstructive jaundice. J Clin Invest 1968;47:809-22.
- Cooper RA, Kimble DB, Durocher JR. Role of the spleen in membrane conditioning and hemolysis of spur cells in liver disease. $N$ Engl $J$ Med 1974;290:1279-84.

${ }^{7}$ Cooper RA, Arner EC, Wiley JS, Shattil S. Modification of red cell membrane structure by cholesterol-rich lipid dispersion: a model for the primary spur cell defect. J Clin Invest 1975;55:115-6.

${ }^{8}$ Nagasaki T, Akanuma Y. A new colorimetric method for determination of plasma lecithin-cholesterol acyltranspherase activity. Clin Chim Acta 1977;75:371-5.

${ }^{9}$ Allain CC, Poon LC, Chan CSG, Richimond W, Fu PC. Enzymatic determination of total serum cholesterol. Clin Chem 1974;20:470-5.

${ }^{10}$ Lowry OH, Rosebrough NJ, Farr AL, Randall RJ. Protein measurement with the folin phenol reagent. J Biol Chem 1951;193:265-75.

${ }_{11}$ Shin YS. Spectrophotometric ultramicrodetermination of inorganic phospholus and lipid phospholus in serum. Anal Chem 1962;34:1164-70.

${ }^{12}$ Horiuchi K, Horiguchi S, Shinagawa K, Takada F, Teramoto K. A polarographic method for the determination of a small amount of lead in biological materials. Osaka City Med J 1968;14:113-8.

${ }^{13}$ Tomokuni K, Ogata M. Simple method for determination of urinary $\delta$-aminolevulinic acid as index of lead exposure. Clin Chem 1972;18:1534-6.

${ }^{14}$ Sano S, Granick S. Mitochondrial coproporphyrinogen oxidase and protoporphyrin formation. $J$ Biol Chem $1961 ; 236: 1173-80$.

${ }^{15}$ Aub JC, Reznikoff P. The effects of lead in red blood cells. J Exp Med 1924;40:189-93.

${ }^{16}$ Griggs RC. Lead poisoning: Hematologic aspects. Prog Hematol 1964;4:117-37.

${ }^{17}$ Karai I, Fukumoto K, Horiguchi S. The effect of lead on erythrocyte osmotic fragility. Proceeding of 54th annual meeting of Japan Association of Industrial Health, April 5-8, 1981. Tokushima, Japan: Japan Association of Industrial Health, $1981: 210-1$. (In Japanese.) 